\title{
RATE SISWA TUNAGRAHITA RINGAN DALAM BELAJAR PENYETELAN RANTAI SEPEDA MOTOR DENGAN METODE DEMONSTRASI
}

\author{
Horen Pujiono ${ }^{1}$, Wahid Munawar ${ }^{2}$, Sriyono $^{3}$ \\ Universitas Pendidikan Indonesia \\ Jl. Dr. Setiabudhi No. 229 Bandung 40154 \\ horen.oren@gmail.com
}

\begin{abstract}
ABSTRAK
Penelitian ini berkaitan tentang kejadian atau perilaku anak tersebut dalam priode waktu tertentu atau yang di sebut dengan istilah rate. Tujuan penelitian ini untuk menemukan metode pembelajaran yang sesuai dengan anak tunagrahita. Metode yang akan diterapkan metode demonstrasi. Metode demonstrasi yang lebih mengedepankan visualisasi akan memudahkan anak tunagrahita untuk menyerap informasi dan mengerti akan maksud isi pembelajaran. Metode penelitian yang digunakan adalah metode deskriptif dengan subjek tunggal. Metode penelitian ini bertujuan untuk memodifikasi perilaku, dimana pengambilan dan pengolahan data dalam metode ini difokuskan untuk melihat perubahan prilaku subjek. Apakah ada atau tidaknya pengaruh intervensi terhadap target behavior dalam fase yang telah ditentukan. Desain penelitian menggunakan desain reversal tipe A-B-A, dimana pengukuran fase baseline (A1) dilakukan sebelum fase intervensi, kemudian dilakukan fase baseline (A2). Fase baseline (A1) dan fase baseline (A2) dilakukan sebanyak tiga kali, sedangkan fase intervensi dilakukan sebanyak empat kali. Penelitian dilakukan terhadap anak tunagrahita tingkat SMALB Citeureup Kota Cimahi, berdasarkan hasil penelitian pada pelaksanaan penyetelan rantai sepeda motor terdapat beberapa rate yang terjadi pada kedua siswa, yaitu: (1) Ngobrol, (2) Tengok Kanan tersenyum, (3) Menjauh.
\end{abstract}

Kata kunci: metode demonstrasi, rantai sepeda motor, rate, otomotif.

\section{PENDAHULUAN}

Pendidikan bagi anak berkebutuhan khusus (ABK) disekolah reguler dan sekolah luar biasa (SLB), hakekatnya untuk membantu anak mengembangkan potensinya. Bagi lembaga pendidikan (SLB/SMALB dan sekolah inklusi) adalah sangat diperlukan pola pendidikan yang dengan sengaja dirancang untuk menghasilkan lulusan SLB/SMALB dan sekolah inklusi yang memiliki kompetensi vokasional yang relevan dengan kebutuhan lapangan kerja yang sesuai standar minimal pekerjaan di dunia kerja seperti keterampilan dasar otomotif.

Kenyataannya kondisi pendidikan khusus (SLB/SMALB) sekarang ini, guru yang mengajar keterampilan otomotif bukanlah guru khusus lulusan dari lembaga di bidang teknik otomotif. Sebagaimana dikemukakan oleh Kepala Sekolah SLB Citeureup Kota Cimahi pembelajaran vokasional khususnya di bidang otomotif, belum ada guru yang relevan dengan bidang tersebut (Syaiful, 2010). Anak tunagrahita yang memiliki kecerdasan di bawah rata-rata. Untuk mendapatkan informasi dan kebiasaan siswa tersebut

\footnotetext{
${ }^{1}$ Mahasiswa Departemen Pendidikan Teknik Mesin FPTK, UPI

${ }^{2}$ Dosen Departemen Pendidikan Teknik Mesin FPTK, UPI

${ }^{3}$ Dosen Departemen Pendidikan Teknik Mesin FPTK, UPI
} 
agar dapat menentukan metode pembelajaran yang sesuai dan mengembangkan atau membantu siswa tunagrahita. Pembelajaran keterampilan vokasional untuk siswa tunagraita sangat berbeda dengan siswa normal. Pembelajaran keterampilan anak tunagrahita tentunya memerlukan metode yang disesuaikan dengan kemampuan anak tersebut. Metode belajar yang digunakan akan mempengaruhi terhadap hasil belajar. Metode harus lebih efektif apabila siswa dibimbing dan langsung mengalami sendiri materi yang dipelajari (Sanjaya, 2012). Metode pembelajaran yang sesuai dengan kebutuhan peserta didik akan mempercepat pemahaman terhadap materi yang disampaikan. Metode demonstrasi adalah metode yang dipandang relevan dan tepat untuk proses pembelajaran keterampilan bagi peserta didik tunagrahita. Metode pembelajaran demonstrasi adalah model mengajar yang memperlihatkan bagaimana melakukan sesuatu kepada peserta didik

Belajar merupakan akibat adanya interaksi antara stimulus dan respon. Seseorang dianggap telah belajar sesuatu jika dia dapat menunjukkan perubahan perilakunya. Hampir semua kecakapan, keterampilan, pengetahuan, kebiasaan, kegemaran dan sikap manusia terbentuk dan berkembang karena belajar. Peneliti menyimpulkan bahwa belajar adalah proses yang menghasilkan suatu perubahan perilaku sebagai akibat dari interaksi yang belajar dengan lingkungannya. Penelitian ini akan mendeskripsikan bagaimana rate siswa dalam pembelajarn penyetelan rantai. Pengertian rate dari berbagai pendapat mengarah pada suatu kejadian dalam kurun waktu tertentu. Rate dalam pembahasan ini adalah suatu kejadian yang dilakuan siswa dalam proses pembelajaran keterampilan penyetelan rantai sepeda motor.

Anak dengan karakteristik khusus yang berbeda dengan anak pada umumnya yaitu ketidakmampuan mental, emosi atau fisik. Anak berkebutuhan khusus secara fisik memiliki kekurangan (cacat) namun pada dasarnya memiliki kemampuan yang dapat dikonstruksi secara sosial, di Indonesia anak yang berkebutuhan khusus antara lain: tunanetra, tunarungu, tunawicara, tunadaksa, tunagrahita, tunalaras (Effendi, 2006). Penelitian ini berorientasi pada anak berkebutuhan khusus yaitu anak tunagrahita, karena karakteristik dan hambatan yang dimiliki anak tunagrahita memerlukan bentuk pelayanan pendidikan khusus yang disesuaikan dengan kemampuan dan potensi mereka. Retardasi mental merupakan kata lain dari tunagrahita. Anak tunagrahita karena keterbatasan kecerdasanya mengakibatakan sulit untuk mengikuti pembelajaran disekolah biasa, oleh karena itu anak tunagrahita membutuhkan layanan pendidikan khusus yakni disesuaikan dengan kemampuan anak tersebut. Keterbatasan inteligensi pada anak tunagrahita 
merupakan ketidak mampuan seperti mempelajari informasi dan keterampilanketerampilan menyesuaikan diri dengan masalah atau situasi kehidupan (Suryosubroto, 2002).

Sepeda motor memiliki sistem pemindah tenaga dari engine ke penggerak akhir (final drive). Final drive adalah bagian terakhir dari sistem pemindah tenaga yang memindahkan tenaga engine ke roda belakang. Final drive juga berfungsi sebagai gigi pereduksi untuk mengurangi putaran dan menaikkan momen (tenaga), biasanya perbandingan gigi reduksinya berkisar antara 2,5 sampai 3 berbanding 1 (2,5 atau 3 putaran dari transmisi akan menjadi 1 putaran pada roda). Kendaraan roda dua yang baik membutuhkan perawatan secara rutin pada komponennya, istilah lain melakukan service.

\section{METODE PENELITIAN}

Metode penelitian yang digunakan adalah deskripsi dengan subjek tunggal. Metode deskriptif adalah suatu metode dalam meneliti status sekelompok manusia, suatu obyek, suatu set kondisi, suatu sistem pemikiran, ataupun suatu kelas peristiwa pada masa sekarang. Tujuan dari penelitian ini adalah untuk membuat deskripsi, gambaran atau lukisan secara sistematis, faktual dan akurat mengenai fakta-fakta, sifat-sifat serta hubungan antar fenomena yang diselidiki. Partisipan penelitian ini adalah siswa SMALB Citereup Kota Cimahi pada pembelajaran keterampilan otomotif dasar penyetelan rantai sepeda motor terdapat dua subjek atau siswa yang keduanya memiliki difabilitas yang sama yaitu tunagrahita. Instrumen yang digunakan adalah observasi yang terkait dengan sikap dan tes untuk mengukur pengetahuan responden.

\section{HASIL PENELITIAN}

Hasil penelitian diperoleh dengan melakukan pengamatan dan observasi langsung selama proses praktik keterampilan penyetelan rantai sepeda motor pada siswa tunagrahita ringan. Pengamatan dilakukan dengan desain A1-B-A2 dengan 10 fase dibagi menjadi baseline (A1) dilakukan sebanyak 3 kali dengan kemampuan sendiri atau dimana kondisi siswa belum sama sekali mendapatkan intervensi atau perlakuan, fase intervensi (B) dilakukan sebanyak 4 kali dengan cara memberikan intervensi atau perlakuan kepada siswa untuk mengubah target behavior siswa, kemudian fase baseline (A2) dilakukan sebanyak 3 kali setelah adanya intervensi kepada siswa. 
Fase baseline (A1) diberikan agar peneliti dapat mengetahui kemampuan yang dimiliki dari siswa tersebut berdasarkan kemampuan sendiri. Siswa pada fase ini sama sekali tidak memiliki kemampuan untuk melakukan penyetelan rantai sepeda motor maupun menggunakan alat, siswa cenderung bingung untuk melakukan praktik walaupun sudah diberi job sheet, hal ini dikarenakan siswa belum sama sekali melakuan praktik penyetelan rantai sepeda motor.

Fase intervensi (B) yaitu dengan memberikan suatu intervensi agar siswa tersebut dapat terarah dan lebih mengerti tentang apa yang harus mereka lakukan pada proses penyetelan rantai sepeda motor. Tahap pertama yang dilakukan adalah memberi arahan tentang persiapan kelengkapan praktik, penggunaan alat dan bahan yang akan digunakan dengan melihat tahapan kerja pada job sheet. Setelah siswa mengerti dilanjutkan dengan mempraktikan langsung kepada siswa seperti cara menggunakan kuas, kunci ring, kunci pas dan penggunaaan pelumas rantai. Selanjutnya siswa melakukan praktik penyetelan rantai sepeda motor dengan mengikuti tahapan kerja pada job sheet serta di dampingi dan di arahkan oleh guru. Fase intervensi (B) ini dilakukan 4 kali dikarenakan sudah stabil. Kemampuan siswa pada tahapan ini lebih baik dari sebelumnya yang sama sekali tidak dapat melakukan praktik penyetelan rantai sepeda motor. Hambatan pada fase intervensi (B) yaitu siswa belum dapat melakukan tahapan-tahapan pekerjaan pada job sheet dan penggunaan alat jika tidak diarahkan oleh guru, dan setiap kali perpindahan tahapan pekerjaan siswa diam dan menunggu perintah atau arahan dari guru jika tidak siswa jadi fokus ke hal disekitarnya seperti mengobrol, tengok kana dan tersenyum, bahkan menjauh meninggalkan pekerjaanya. Hambatan yang terjadi di atas merupakan rate.

Fase baseline (A2) kemampuan praktik siswa di fase ini dilakukan sebanyak 3 kali sesudah fase intervensi, pada tahapan ini siswa langsung melakukan praktik. Kesulitan atau hambatan siswa pada fase ini yaitu mengawali praktik karena lupa, hal ini dikarenakan siswa melakukan praktik ada jeda hari di tiap sesinya dan ini imbas dari masalah minat atau keinginan siswa yang kurang, jika siswa tidak mau melakukan praktik maka siswa tidak bisa dipaksakan karena terlihat dari kegelisahan siswa saat praktik bahkan siswa meminta pulang ketika melihat ada siswa lain pulang, hal ini juga pernah terjadi di fase A1 dan B. Rate pada tahapan ini masih tetap ada, namun setelah guru mengingatkan tahapan awal praktik barulah siswa mulai melakukan praktik. 


\section{PEMBAHASAN}

Hasil dari metode demonstrasi pada pembelajaran otomotif dasar penyetelan rantai sepeda motor yang diterapkan pada anak tunagrahita. Hasilnya menunjukkan bahwa siswa tersebut dapat mengikuti dan mempraktikan kembali apa yang didemonstrasikan oleh guru, kedua siswa dapat melaksanakan proses persiapan: baju praktik dan sepatu praktik dipakai dengan benar, tempat kerja disiapkan siswa dengan benar, lembar kerja (job sheet) perawatan rantai sepeda motor disimak, benda kerja disiapkan, peralatan kerja disiapkan (Moelyani, 2001). Proses pelaksanaan: siswa dapat putar kunci kontak ke posisi off, masukan gigi pada posisi netral, letakan sepeda motor diatas standar utama, periksa jarak main bebas rantai, melonggarkan mur baut poros roda belakang, menyetel rantai, mengencangkan mur baut poros roda belakang, kencangkan kedua mur penyetelan, periksa kembali jarak main, bersihkan rantai dan lumasi rantai dengan pelumas rantai.

Rate adalah suatu kejadian yang dilakuan siswa dalam periode waktu yang berbeda, yaitu meneliti bagaimana rate siswa dalam penyetelan rantai sepeda motor berbantuan metode demonstrasi. Selama hasil penelitian, peneliti menemukan rate yang dilakukan siswa selama praktik penyetelan rantai sepeda motor yaitu: 1) ngobrol, 2) tengok, 3) menjauh.

Rate pada fase baseline A1 tidak terjadi rate karena siswa tidak mau melakukan praktik mereka cenderung tidak mau mencoba untuk praktik walaupun sudah diberi perintah (Sutjihati, 2007). Hal ini terjadi karena siswa tidak pernah sebelumnya melakukan praktik keterampilan penyetelan rantai sepeda motor. Data rate siswa tidak bisa di ambil karena siswa tidak praktik.

Rate pada fase intervensi ini adalah ngobrol yang terjadi untuk siswa 1 pada fase intervensi (B) dapat dijabarkan sebagai berikut: pada sesi 1 selama 64 detik, sesi 2 selama 33 detik, sesi 3 selama 33 detik, sesi 4 selama 33 detik, adapun perilaku ngobrol tersebut selama 163 detik (2,7 menit) masing-masing adalah 3, 2, 2, 2 kali, dengan demikian perilaku ngobrol tersebut adalah 9 dibagi 2,7 (menit) samadengan 3,3 kali/menit. Tengok yang terjadi untuk siswa 1 pada fase intervensi (B) dapat dijabarkan sebagai berikut: pada sesi 1 selama 7 detik, sesi 2 selama 2 detik, sesi 3 selama 2 detik, sesi 4 selama 4 detik, adapun perilaku tengok tersebut selama 15 detik (0,25 menit) masing-masing adalah 3,1 , 1, 2 kali, dengan demikian perilaku tengok tersebut adalah 7 dibagi 0,25 (menit) sama dengan $28 \mathrm{kali} / \mathrm{menit}$

Ngobrol yang terjadi untuk siswa 2 pada fase intervensi (B) dapat dijabarkan sebagai berikut: pada sesi 1 selama 64 detik, sesi 2 selama 0 detik, sesi 3 selama 56 detik, 
sesi 4 selama 0 detik, adapun perilaku ngobrol tersebut selama 120 detik ( 2 menit) masingmasing adalah 5, 0, 3, 0 kali, dengan demikian perilaku ngobrol tersebut adalah 8 dibagi 2 (menit) samadengan $4 \mathrm{kali} /$ menit. Tengok yang terjadi untuk siswa 2 pada fase intervensi (B) dapat dijabarkan sebagai berikut: pada sesi 1 selama 12 detik, sesi 2 selama 9 detik, sesi 3 selama 8 detik, sesi 4 selama 9 detik, adapun perilaku tengok tersebut selama 38 detik (0,63 Menit) masing-masing adalah 5, 4, 3, 4 kali, dengan demikian perilaku tengok tersebut adalah 16 dibagi 0,63 (menit) sama dengan 25,3 kali/menit.

Menjauh yang terjadi untuk siswa 2 pada fase intervensi (B) dapat dijabarkan sebagai berikut: pada sesi 1 selama 0 detik, sesi 2 selama 7 detik, sesi 3 selama 13 detik, sesi 4 selama 17 detik, adapun perilaku menjauh tersebut selama 37 detik (0,61 menit) masing-masing adalah $0,1,2,2$ kali, dengan demikian perilaku menjauh tersebut adalah 5 dibagi 0,61 (menit) samadengan 8,1 kali/menit.

Ngobrol yang terjadi untuk siswa 1 pada fase Baseline (A2) dapat dijabarkan sebagai berikut: pada sesi 1 selama 35 detik, sesi 2 selama 27 detik, sesi 3 selama 18 detik, adapun perilaku ngobrol tersebut selama 80 detik (1,33 menit) masing-masing adalah 2, 2, 1 kali, dengan demikian perilaku ngobrol tersebut adalah 5 dibagi 1,33 (menit) samadengan 3,75 kali/menit.

Tengok yang terjadi untuk siswa 1 pada fase baseline (A2) dapat dijabarkan sebagai berikut: pada sesi 1 selama 4 detik, sesi 2 selama 7 detik, sesi 3 selama 5 detik, adapun perilaku tengok tersebut selama 16 detik (0,26 menit) masing-masing adalah 2, 3, 2 kali, dengan demikian perilaku tengok tersebut adalah 7 dibagi 0,26 (menit) sama dengan $26,92 \mathrm{kali} / \mathrm{menit}$.

Tengok yang terjadi untuk siswa 2 pada fase baseline (A2) dapat dijabarkan sebagai berikut: pada sesi 1 selama 10 detik, sesi 2 selama 16 detik, sesi 3 selama 13 detik, adapun perilaku tengok tersebut selama 39 detik (0,65 menit) masing-masing adalah 5, 7, 6 kali, dengan demikian perilaku ngobrol tersebut adalah 18 dibagi 0,65 (menit) samadengan $27,69 \mathrm{kali} / \mathrm{menit}$.

Menjauh yang terjadi untuk siswa 2 pada fase baseline (A2) dapat dijabarkan sebagai berikut: pada sesi 1 selama 23 detik, sesi 2 selama 9 detik, sesi 3 selama 15 detik, adapun perilaku menjauh tersebut selama 47 detik (0,78 menit) masing-masing adalah 3,1 , 2 kali, dengan demikian perilaku menjauh tersebut adalah 6 dibagi 0,78 (menit) sama dengan 7,69 kali/menit. 


\section{KESIMPULAN}

Kesimpulan penelitian ini bahwa metode demonstrasi dapat diaplikasikan di pada siswa yang tunagrahita ringan. Rate yang dilakukan oleh siswa dalam pelaksaan pembelajaran praktik penyetelan rantai sepeda motor. Pelaksanaan pembelajaran otomotif penyetelan rantai sepeda motor dengan menggunakan metode demonstrasi pada siswa tunagrahita ringan dapat diaplikasikan dimana siswa dapat mengikuti dan mempraktikan kembali apa yang didemonstrasikan oleh guru. Proses pembelajaran siswa tunagrahita ringan dalam implementasi alternatif model pembelajaran keterampilan vokasional teknologi otomotif melalui pendekatan pembelajaran latihan keterampilan dengan demonstrasi pada kompetensi penyetelan rantai sepeda motor terdapat beberapa rate yang terjadi pada kedua siswa, yaitu: ngobrol, tengok kanan, menjauh.

\section{REFERENSI}

Effendi, M. (2006). Pengantar Psikopedagogik Anak Berkelainan. Jakarta: Bumi Askara. Moelyani, S. R. (2001). Strategi Belajar Mengajar.Jakarta: Rineka Cipta.

Sanjaya. (2012). Strategi Pembelajaran. Jakarta: Kencana Prenada Media Group.

Suryosubroto. (2002). Beberapa Aspek Dasar-Dasar Kependidikan. Jakarta: PT. Rineka Cipta.

Sutjihati, S. (2007). Psikologi Anak Luar Biasa. Bandung: PT. Refika Aditma.

Syaiful. (2010). Guru dan Anak Didik dalam Interaksi Edukatif. Jakarta: Rineka Cipta. 